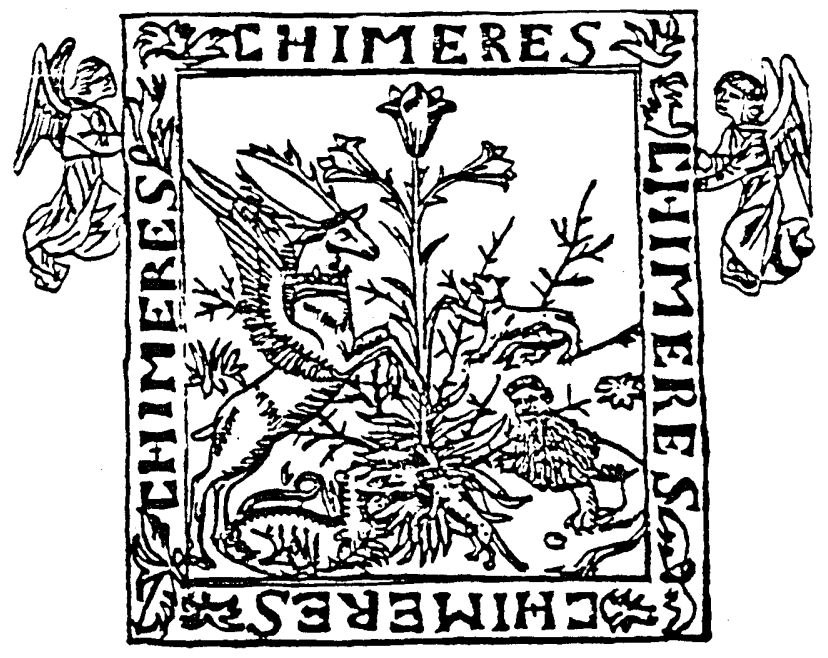

A Journal
of French and
Italian Literature

Volume XIV,

Number 1 
Chimères is a literary journal published each academic semester (Spring and Fall numbers) by the graduate students of the Department of French and Italian at the University of Kansas. The editors welcome the submission of papers written by non-tenured Ph.D's and advanced graduate students which deal with any aspect of French or Italian literature, language, or culture. We will consider any critical study, essay, bibliography, or book review. Such material may be submitted in English, French, or Italian. In addition, we encourage the submission of poems and short stories written in French or Italian.

Manuscripts must conform to the MLA Style Sheet and should not exceed 15 pages in length. All submissions should be double-spaced and be clearly marked with the author's name and address. Please submit all material in duplicate. If return of the material is desired, please enclose a stamped, self-addressed envelope.

The annual subscription rate is $\$ 4$ for individuals and $\$ 10$ for libraries and institutions.

Chimères is published with funds provided in part by the Student Activity Fee through the Graduate Student Council of the University of Kansas.

Please direct all manuscripts, subscriptions, and correspondence to the following address:

Editor, Chimères

Department of French and Italian

University of Kansas

Lawrence, Kansas 66045 


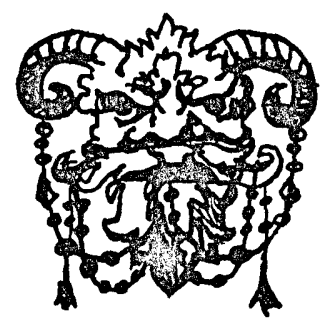

Rédacteur: Raymond E. Whelan

Collaborateurs:

Suzanne Hamilton

Erica Hill

Paul Homan

Glenda Warren

Conseillers universitaires:

John T. Booker

Jean-Pierre Boon

David A. Dinneen

$\mathrm{J}$. Theodore Johnson, Jr.

Norris J. Lacy

Kenneth White

John Williams

(C) 1980 by Chimères 


\section{TABLE DES MATIERES}

MARY DUGAN

L'Aveugle et la conscience dans Madame

Bovary . . . . . . . . . . 5

HELEN KNODE

The Narrator's Quest in Du côtè de

chez Swann . • • . • • • • . . 15

ALETA RAY

Rules of the Game: Characterization of Robert de la Chesnaye. . . . . . . 28

SARA ANN RUGE

Artistic Creation as an Act in Sartre's

Nausea . . . . . . . . . . 41

KENNETH WHITE

Immergés, colorés maintenant de brouil-

ard. . . . . . . . . . 57

CHARLENE SACKS

En revoyant Eurydice d'Anouilh . . . . 60

TON THAT DONG-NAI

L'Héroîne moderne de Camus: une étude

de trois femmes. . . . . . . . 73 
The editorial board of Chimères wishes to express gratitude to the Helen Foresman Spencer Museum of Art, The University of Kansas, for the kind permission to reproduce photographs of the following works from its collection: Au clair de la lune (Pierre Puvis de Chavannes, 1885), p. 4; Double Portrait of Valentine Hugo as "Queen of Diamonds" (Man Ray, 1935), p. 21; Place Pigalle (Albert André, 1938), p. 40; Still Life with Tube of Paint (Louis Marcoussis, 1921), p. 56; and Travesty-Red Background (Bernard Buffet, 1953), p. 72; to Professor JeanPierre Boon, for the photographs which appear on pages 28 and 35; and to Professor Norris J. Lacy, for the photograph which appears on page 59 . 


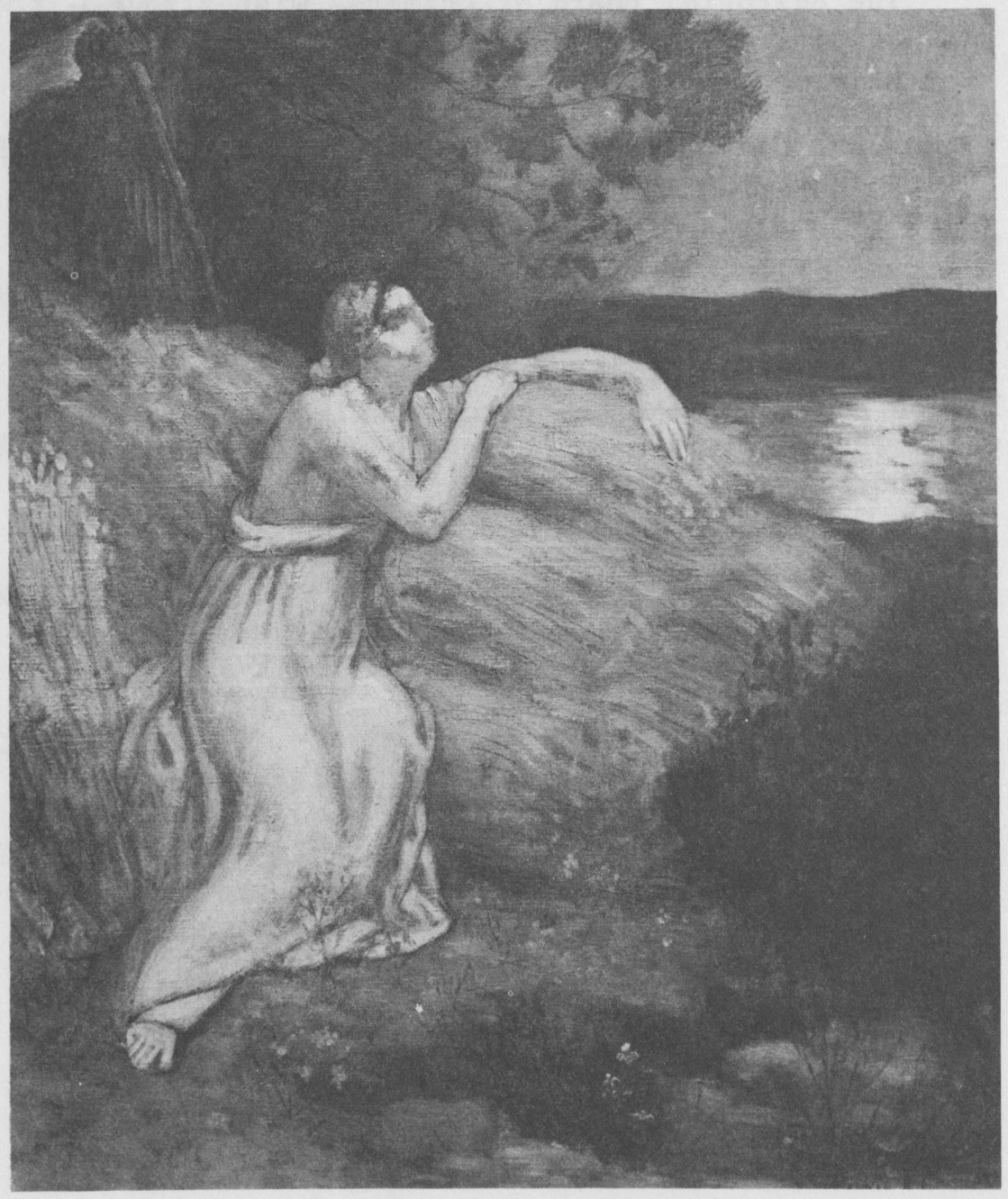

